\title{
Fragmentation and Nondisjunction of Barley Chromosomes After the Treatment of Chloramphenicol and Cycloheximide
}

\author{
Hisashi Yoshida, Koji Yamamoto and Hikoyuki Yamaguchi \\ Laboratory of Radiation Genetics, Faculty of Agriculture, \\ University of Tokyo, Tokyo 113, Japan
}

Received April 13, 1971

It has been well known that chromosome breakage is induced by various metabolic inhibitors, for example, which interfere with some important synthetic processes of cell constituents. The relationship between primary chromosomal damage and metabolic alteration remains obscure due to the complexity of chromosome structure.

There are some reports that each treatment of the following three antibiotics does not induce chromosome breakage; chloramphenicol (CAP) in mice (De Lozzio et al. 1965) and Tradescantia microspores (Beatty et al. 1963), cycloheximide (CH) in human lymphocytes (Wolff 1969) and puromycin (PU) in Tradescantia microspores (Beatty et al. 1963).

However, De (1968) observed that CAP produced chromosomal breaks in root tip cells of onion, and suggested that CAP was active chiefly in $\mathrm{G}_{1}$.

In this study, chromosome changes were induced by three antibiotics known as an inhibitor of protein synthesis (CAP, $\mathrm{CH}$ or PU), given at various stages of the cell cycle in barley root tip cells.

\section{Materials and methods}

Seeds of naked barley (Hordeum vulgare cultivar. Ehimehadaka No. 1) were used throughout this experiment. In order to obtain uniform germination as possible, seeds were selected with a specific gravity using $\mathrm{NaCl}$ solution and then were stored for 30 days at $35 \pm 2^{\circ} \mathrm{C}$. They were used in each experiment. According to the method of Yamamoto and Yamaguchi (1966), primary roots in which cells started the first mitotic division with a partial synchronization were prepared. Twenty seeds were planted in each $\mathrm{L}$ tube containing $2.5 \mathrm{ml}$ distilled water and were germinated with shaking culture $(50 \mathrm{cycles} / \mathrm{min})$ at $25^{\circ} \mathrm{C}$. At the $33 \mathrm{rd}$ hour after the soaking began, all root tips were fixed in absolute ethanol and glacial acetic acid (3:1) solution. They were hydrolyzed in $\mathrm{N} \mathrm{HCl}$ at $60^{\circ} \mathrm{C}$ for 12 minutes and squash preparations were made after staining in Feulgen. Anaphase or metaphase cells were scanned for chromosome aberrations.

Treatment of the chemicals

At various times between 18.5 and 29.5th hour after the beginning of soaking, germinated seeds were transferred in each $\mathrm{L}$ tube containing $2.5 \mathrm{ml}$ solution with 
$300 \mu \mathrm{g} / \mathrm{ml}$ of chloramphenicol (CAP; Sankyo Chemicals, Tokyo), $10 \mu \mathrm{g} / \mathrm{ml}$ of cycloheximide ( $\mathrm{CH}$; gift from Agricultural Chemicals Inspection Station, Tokyo) or $50 \mu \mathrm{g} / \mathrm{ml}$ of puromycin (PU; Nutritional Biochemicals, New York). After shaken for 1 hour at $25^{\circ} \mathrm{C}$, they were rinsed repeatedly in distilled water, and were cultured again until fixation. The $\mathrm{pH}$ of each chemical solution was 5.0 to 5.5. In order to clarify the dose-effect relationship, $\mathrm{CAP}, \mathrm{CH}$ or $\mathrm{PU}$ of various concentrations were administered at 21.5 to 22.5 th hour after the soaking began.

\section{Counting of chromosome number}

At 21.5th hour after the beginning of soaking, twenty germinated seeds were transferred in each L tube containing $2.5 \mathrm{ml}$ solution of CAP $(300 \mu \mathrm{g} / \mathrm{ml})$ or $\mathrm{CH}$ $(10 \mu \mathrm{g} / \mathrm{ml})$. After the treatment of $1,2,3$ or 4 hours with shaking culture at $25^{\circ} \mathrm{C}$, they were rinsed repeatedly in distilled water and were grown again. For accumulation of metaphase cells, seeds were incubated with $0.2 \%$ colchicine solution (Wako Pure Chemicals, Tokyo) for the last 2 hours before fixation. Squash preparation was made by Feulgen procedure, and the counting of chromosomes was made in metaphase cell.

\section{Autoradiography}

1) Incorporation of ${ }^{3} \mathrm{H}$-thymidine in the interphase cell treated with CAP

At various times in the cell cycle, twenty germinated seeds were cultured with a $2.5 \mathrm{ml}$ mixed solution of CAP $(0,150$ or $300 \mu \mathrm{g} / \mathrm{ml})$ and $2 \mu \mathrm{Ci} / \mathrm{ml}{ }^{3} \mathrm{H}$-thymidine $\left({ }^{3} \mathrm{H}\right.$-thymidine-6, T(N); The Radiochemical Centre, Amersham, England; specific radioactivity $20.2 \mathrm{Ci} / \mathrm{mM}$ ) for 1 hour with shaking at $25^{\circ} \mathrm{C}$. After rinsed in distilled water, they were transferred to $2.5 \mathrm{ml}$ thymidine solution $\left(1 \times 10^{-5} \mathrm{M}\right.$, Schwarz Bioresearch Inc., New York) and were grown until fixation. Then, squash preparations were carried out with the Feulgen procedure. The cover slips were removed on dry ice. Each slide was dipped into Sakura autoradiographic emulsion (NRM2, Tokyo). After exposed for 3 weeks at room temperature, the slides were developed in "Sakura" Konidol X for 4 minutes. The presence or absence of labeled chromosome was scored in 200 anaphase cells per each treatment. Only the cells having 5 or more silver grains on the chromosome were counted as actually labeled. Background was corrected for estimate of silver grains.

2) Incorporation of ${ }^{3} \mathrm{H}$-lysine in the interphase cell treated with $\mathrm{CAP}$ or $\mathrm{CH}$

At 21.5th hour after the beginning of soaking, twenty germinated seeds were transferred in each $\mathrm{L}$ tube containing $2.5 \mathrm{ml}$ mixed solution of ${ }^{3} \mathrm{H}-$ lysine $(6 \mu \mathrm{Ci} / \mathrm{ml}$; DL-lysine-4,5-monohydrochloride; New England Nuclear, Mass.; specific radioactivity $5.3 \mathrm{Ci} / \mathrm{mM})$ with and without CAP $(300 \mu \mathrm{g} / \mathrm{ml})$ or CH $(10 \mu \mathrm{g} / \mathrm{ml})$. Immediately after cultured for 1 hour at $25^{\circ} \mathrm{C}$, these seeds were rinsed in distilled water and lysine solution (DL-lysine monohydrochloride; Wako Pure Chemicals) of $3.7 \times$ $10^{-5} \mathrm{M}$. Then, they were fixed in $10 \%$ neutral formalin, adjusted to $\mathrm{pH} 7.0$ with sodium carbonate, for the retention of basic proteins in the cell. One tube, which contained neither $\mathrm{CAP}$ nor $\mathrm{CH}$, was chased in lysine solution for 1 hour and then was fixed. Autoradiography was prepared with the same procedure as mentioned above. 


\section{Results}

Chromosomal aberrations induced in barley root tip cells by the treatment of CAP $(300 \mu \mathrm{g} / \mathrm{ml})$ or $\mathrm{CH}(10 \mu \mathrm{g} / \mathrm{ml})$ is shown in Fig. 1. All the aberrations were the fragment of dot type. These fragments were the chromosome type having a pair of fragments. After the treatment of $\mathrm{CH}$, however, chromatid type giving one fragment in cell appeared about $30 \%$ of all the aberrations, in addition to chromosome type.

The cells in various stages of a mitotic cycle were treated with CAP $(300 \mu \mathrm{g} / \mathrm{ml})$, CH $(10 \mu \mathrm{g} / \mathrm{ml})$ or PU $(50 \mu \mathrm{g} / \mathrm{ml})$ for 1 hour. In Fig. 2, yield of chromosome fragments was plotted at the middle of each treatment time. In $\mathrm{CAP}$ and $\mathrm{CH}$, the frequencies of induced chromosome fragments showed the same variation against mitotic cycle, whereas PU induced no chromosome aberrations. The duration of DNA synthesis (S phase) was determined based on the method of Quastler (1960) (see Fig. 6). From Figs. 2 and 6, it is suggested that chromosome fragments were induced only when $\mathrm{S}$ cells were treated with CAP or $\mathrm{CH}$.
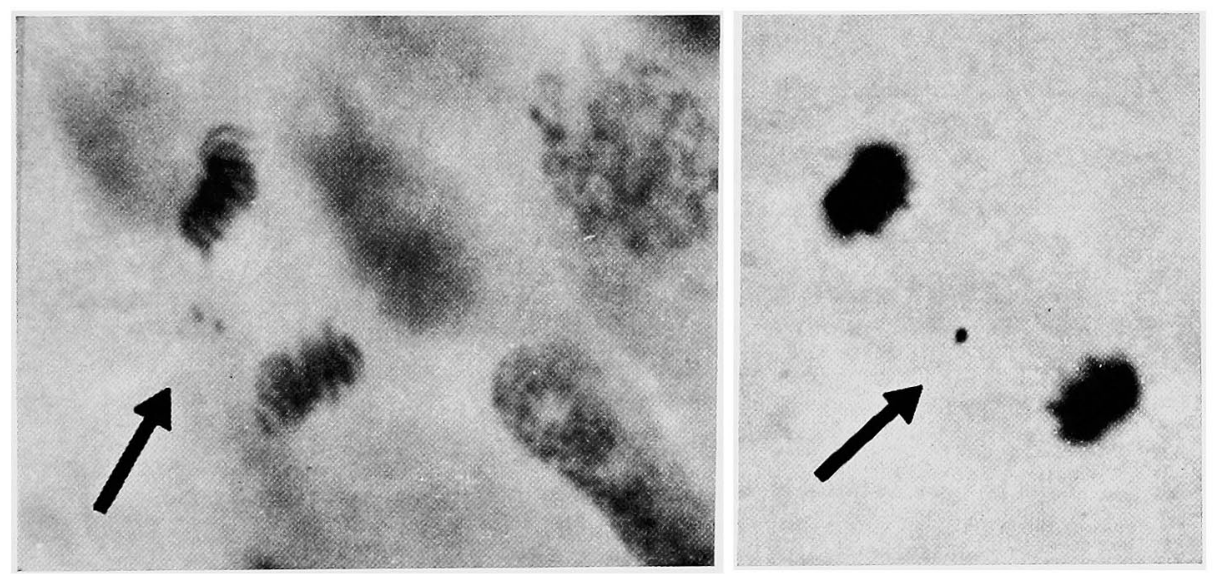

Fig. 1. Chromosome fragments of dot type induced with CAP $(300 \mu \mathrm{g} / \mathrm{ml})$ or $\mathrm{CH}(10 \mu \mathrm{g} / \mathrm{ml})$ treatment of barley root. Chromosome type (left). Chromatid type (right).

This suggestion was supported from the data showing a relation between chromosome fragments and silver grains per cell obtained after 1 hour treatment of the mixed solution of CAP $(150$ or $300 \mu \mathrm{g} / \mathrm{ml})$ plus ${ }^{3} \mathrm{H}$-thymidine $(2 \mu \mathrm{Ci} / \mathrm{ml})$. As seen in Table 1, most chromosome fragments were found in the cells having less than 15 silver grains. Cells with 0 to 15 grains are probably in early $G_{2}$ and early or late $S$, respectively (see Fig. 6). It is possible to conclude, therefore, that chromosome fragments were induced in the cells treated in early $S$, late $S$ and early $G_{2}$. Silver grains, i.e., incorporation of ${ }^{3} \mathrm{H}$-thymidine were not enable to recognize on these chromosome fragments.

The following experiment was carried out to obtain some information about the kinetics of chromosome aberrations induced by CAP or $\mathrm{CH}$. Cells of the early $\mathrm{S}$, a critical stage for the effect of these chemicals, were treated with $\mathrm{CAP}, \mathrm{CH}$ or $\mathrm{PU}$ of the various concentrations for 1 hour. As can be seen from Fig. 3, frequency 


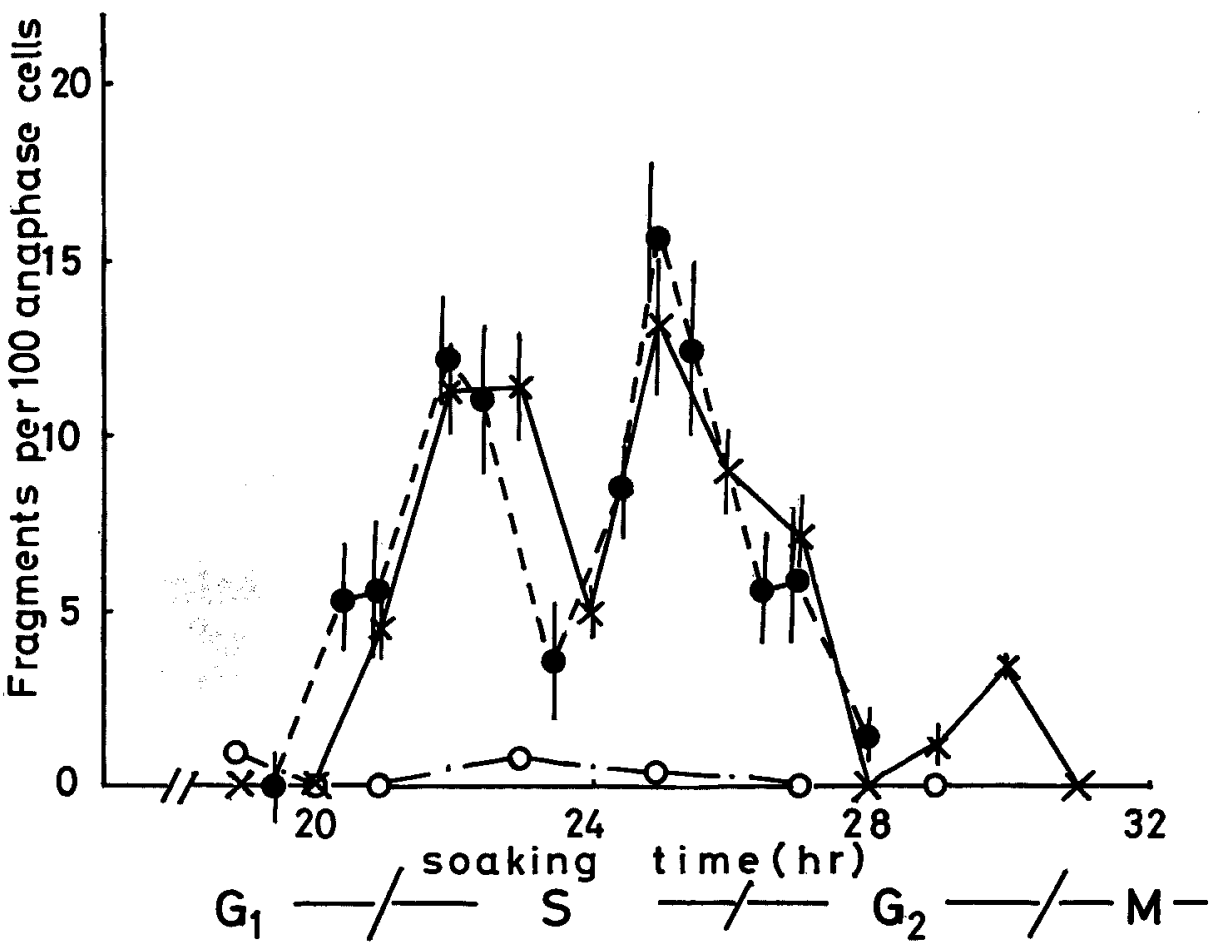

Fig. 2. Chromosome fragments observed in anaphase cells after $1 \mathrm{hr}$-treatment with $\mathrm{CAP}, \mathrm{CH}$ or PU to the cells in various mitotic cycle stages. Confidence limit at $95 \%$ level. CAP (300 $\mu \mathrm{g} /$ $\mathrm{ml}) \times-\times, \mathrm{CH}(10 \mu \mathrm{g} / \mathrm{ml}) \bullet--\bullet$, PU $(50 \mu \mathrm{g} / \mathrm{ml}) \mathrm{O}-\mathrm{O}$.

Table 1. Relationship between chromosome fragments and silver grains in the cells treated with $\mathrm{CAP}+{ }^{3} \mathrm{H}$-thymidine

\begin{tabular}{c|c|c|c|c|c|c|c|c}
\hline \hline \multirow{2}{*}{$\begin{array}{c}\text { Time } \\
\text { (hr) }\end{array}$} & \multicolumn{7}{|c}{ No. of grains } \\
\cline { 2 - 8 } & 0 & $1-4$ & $5-10$ & $11-15$ & $16-20$ & $21-25$ & $26-30$ & $\geq 31$ \\
\hline 20 & & 3 & $(2)$ & & & 1 & & \\
22 & & $10(5)$ & $(2)$ & $5(1)$ & 1 & & & 2 \\
24 & $(1)$ & 4 & 2 & 2 & 2 & & 1 & \\
26 & $5(2)$ & $5(3)$ & $4(3)$ & & & & & \\
28 & 1 & $(2)$ & & & & & & \\
30 & $(3)$ & 3 & & & & & & \\
\hline Total & $6(6)$ & $25(10)$ & $6(7)$ & $7(1)$ & 3 & 1 & 1 & 2 \\
Control & 1 & & & & & & & \\
\hline
\end{tabular}

Mixed solution of ${ }^{3} \mathrm{H}$-thymidine $(2 \mu \mathrm{Ci} / \mathrm{ml})$ and CAP $(150 \mu \mathrm{g} / \mathrm{ml}$ or $300 \mu \mathrm{g} / \mathrm{ml})$ was administered to the cells of various stages in mitotic cycle $(1 \mathrm{hr}$-treatment). Number in bracket shows fragments induced by $150 \mu \mathrm{g} / \mathrm{ml}$ CAP. 200 anaphase cells were scored in each observation. 
of the fragments scored in anaphase cell increased with increasing dose of CAP or $\mathrm{CH}$. Taking into account a decrease of mitotic index and an inhibition of primary root growth, it had to be interpret that the roots treated with more than $600 \mu \mathrm{g} / \mathrm{ml}$ of CAP or $12.5 \mu \mathrm{g} / \mathrm{ml}$ of $\mathrm{CH}$ were affected also secondarily. Consequent-

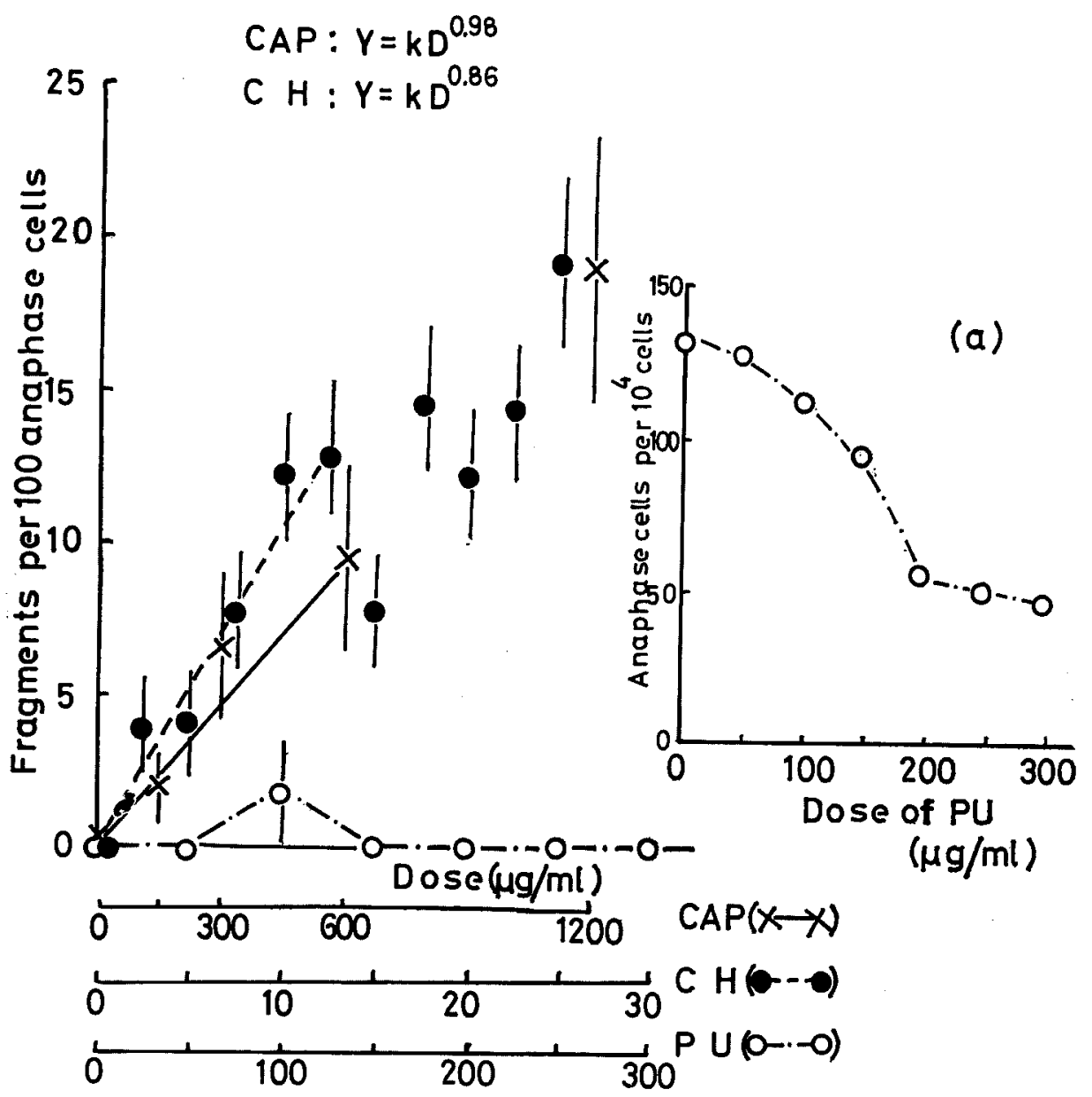

Fig. 3. Effect of dosage on the chromosome fragments produced when CAP, CH or PU is treated to early S cells. (a) Mitotic index (anaphase cells/analyzed cells) in root meristem treated with PU.

ly, the dose-effect relationship was analyzed in relatively lower doses. The yield of fragments is given by

$$
Y=k D^{n}
$$

where $D$ is a dose administered and $k$ or $n$ is a constant.

By a method of least squares, two lines were calculated as shown in Fig. 3. In CAP and CH, $n$ was obtained as 0.98 and 0.86 , respectively. Thus, it is evident that both CAP and $\mathrm{CH}$ induced chromosome fragments by a 1-hit event. 


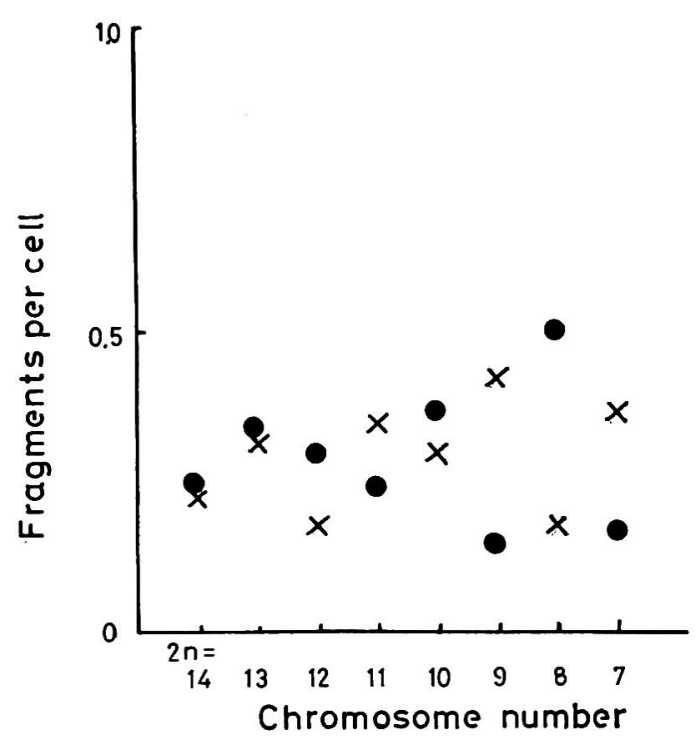

Fig. 5. Correlation between frequency of chromosome fragments and chromosome number. CAP $(300 \mu \mathrm{g} / \mathrm{ml})$ $\times, \mathrm{CH}(10 \mu \mathrm{g} / \mathrm{ml}) \bullet$.

On the other hand, PU did not induced chromosomal aberrations in the concentrations used. Since it is uncertain whether PU could be taken into cell, the number of anaphase cells was also counted. Because mitotic index (anaphase cells per $10^{4}$ cells) decreased with the concentrations of PU (Fig. 3-a), it is evident that PU had reached into cell.

If $\mathrm{CAP}$ or $\mathrm{CH}$ was administered to $\mathrm{S}$ cells, these chemicals not only produced chromosome fragments, but also reduced the chromosomes in a cell. In Fig. 4, left and right photographs show the cell with normal chromosome number $(2=14)$ and the cell with the chromosome number which reduced from 14 to 9 , respectively.
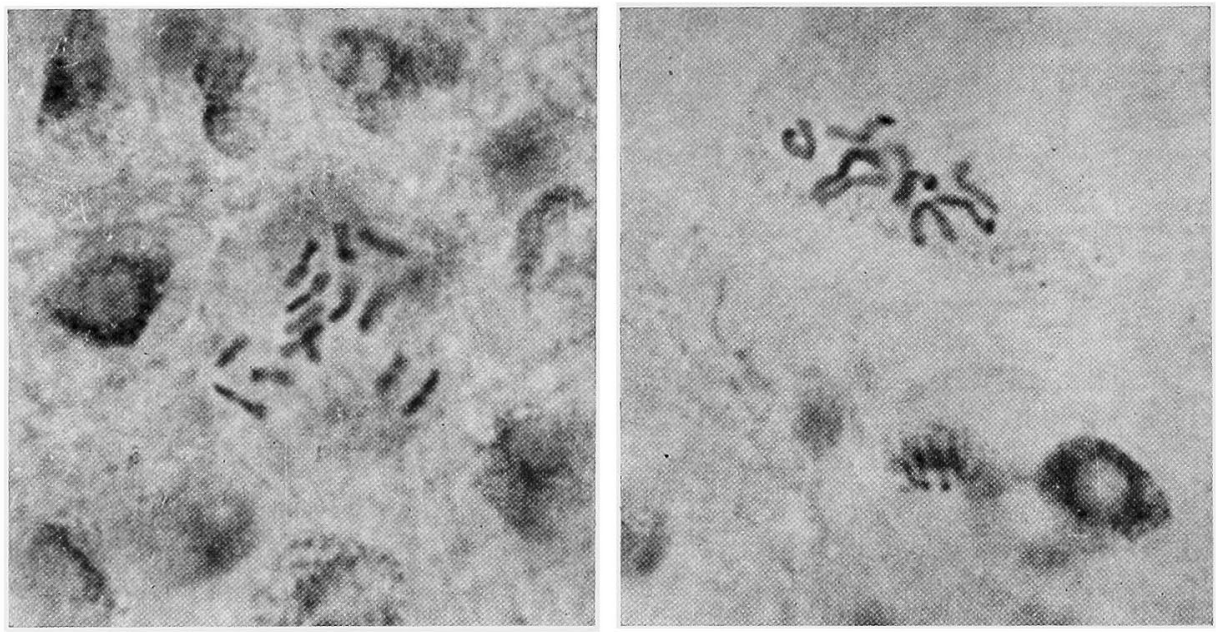

Fig. 4. Reduction of chromosomes in a cell. No. of chromosomes $=14$ (left) and 9 (right).

Relative frequency of the cells having various chromosome numbers is given in Table 2. Chromosome number in a cell varied from $2 n$ to $n$. Cells which reduced the chromosome number increased remarkably by treatment of CAP or $\mathrm{CH}$ in comparison with no treatment. As can be seen from Table 2, frequency of the cells having the reduced chromosome number was about constant independently of various duration of treatment starting from early $\mathbf{S}$. This result suggested that a reduction of chromosome number is mainly due to the event induced in early S. As shown in 
Table 2. Frequency of cells with various number of chromosomes ( $2 n$ to $n$ ) induced by CAP or $\mathrm{CH}$

\begin{tabular}{|c|c|c|c|c|c|c|c|c|c|c|c|}
\hline \multirow{2}{*}{$\begin{array}{c}\text { Chromosome } \\
\text { number }\end{array}$} & \multirow[t]{2}{*}{ Control } & \multicolumn{5}{|c|}{$\begin{array}{c}\text { CAP } \\
\text { Incubation time (hr) }\end{array}$} & \multicolumn{5}{|c|}{$\begin{array}{c}\mathrm{CH} \\
\text { Incubation time }(\mathrm{hr})\end{array}$} \\
\hline & & 1 & 2 & 3 & 4 & mean & 1 & 2 & 3 & 4 & mean \\
\hline $2 n=14$ & $77.4 \%$ & 56.1 & 39.5 & 28.6 & 43.4 & 40.0 & 21.7 & 27.2 & 24.0 & & 24.0 \\
\hline 13 & 12.9 & 6.1 & 9.8 & 17.9 & 11.1 & 12.0 & 15.9 & 19.4 & 16.0 & & 18.7 \\
\hline 12 & 3.2 & 9.8 & 17.4 & 17.9 & 10.1 & 14.8 & 8.7 & 16.5 & 28.0 & & 15.2 \\
\hline 11 & 3.2 & 8.5 & 7.4 & 17.9 & 8.1 & 11.0 & 14.5 & 11.7 & 12.0 & & 12.7 \\
\hline 10 & 0 & 7.3 & 3.7 & 5.6 & 6.1 & 5.0 & 10.1 & 12.6 & 8.0 & & 11.1 \\
\hline 9 & 1.1 & 2.5 & 6.8 & 4.5 & 11.1 & 6.2 & 13.0 & 3.9 & 4.0 & & 7.1 \\
\hline 8 & 1.1 & 7.3 & 8.0 & 3.8 & 5.0 & 6.0 & 8.7 & 3.9 & 0 & & 5.1 \\
\hline 7 & 1.1 & 2.4 & 7.4 & 3.8 & 5.1 & 5.0 & 7.4 & 4.8 & 8.0 & & 6.1 \\
\hline
\end{tabular}

Root tip cells were treated with CAP $(300 \mu \mathrm{g} / \mathrm{ml})$ or CH $(10 \mu \mathrm{g} / \mathrm{ml})$ at the S period, rinsed in distilled water, chased in aerated distilled water and exposed to $0.2 \%$ colchicine solution for the last 2 hours before fixation. Metaphase cells of control were accumulated by treating $0.2 \%$ colchicine solution for the last 2 hours before fixation. Cells treated with $\mathrm{CH}$ for 4 hours were not able to count because mitosis did markedly depress.

Fig. 5, there was no correlation between a reduction of chromosome number and an appearance of chromosome fragment.

Firstly, it was investigated whether CAP depresses DNA synthesis and/or prolongs $\mathrm{S}$ period. After treated with a mixed solution of ${ }^{3} \mathrm{H}$-thymidine $(2 \mu \mathrm{Ci} / \mathrm{ml})$ plus CAP (150 or $300 \mu \mathrm{g} / \mathrm{ml}$ ), silver grains in anaphase cell were counted. As indicated in Fig. 6, labeled cells decreased by treating early $S$ cells with CAP. But, silver grains per labeled cell, i.e. incorporation of ${ }^{3} \mathrm{H}$-thymidine into DNA molecule, did not reduce. This is interpreted as follows; at the

Fig. 6. Labeled anaphase cells after treatment of roots with ${ }^{3} \mathrm{H}$-thymidine $(2 \mu \mathrm{Ci} / \mathrm{ml})$ plus CAP $(0,150,300 \mu \mathrm{g} / \mathrm{ml})$ solution for 1 hour in various mitotic cycle stages. a, labeled cells ( $\%)$, b, grains per labeled cell; CAP, $0 \mu \mathrm{g} / \mathrm{ml}$ $\bigcirc-\bigcirc, 150 \mu \mathrm{g} / \mathrm{ml} \triangle-\cdot \triangle, 300 \mu \mathrm{g} / \mathrm{ml}$
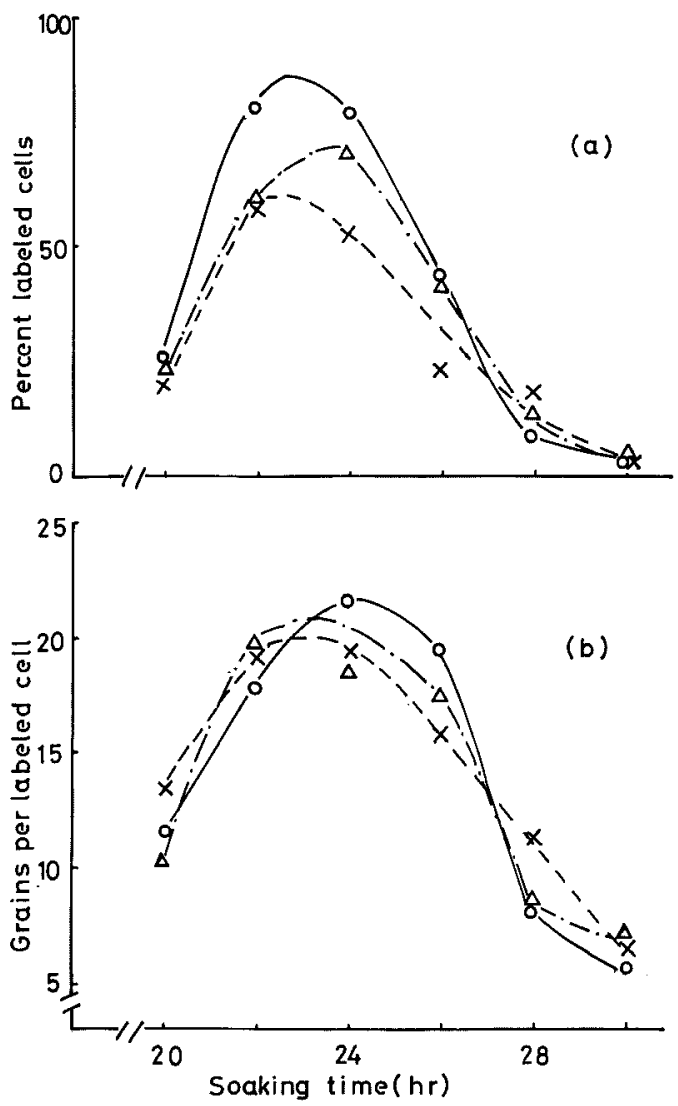
$x---x$. 
moment of CAP treatment, the cells in $G_{1}$ were inhibited the progression of $G_{1}$ to $S$, so-called " $G_{1}$ block", but the cells which had already proceeded to $S$ phase accomplished normally the DNA synthesis even in the presence of CAP.

Secondly, using ${ }^{3} \mathrm{H}$-lysine $(6 \mu \mathrm{Ci} / \mathrm{ml})$, a component of histone, it was investigated whether protein synthesis is inhibitied by treatment of CAP $(300 \mu \mathrm{g} / \mathrm{ml})$ or $\mathrm{CH}$

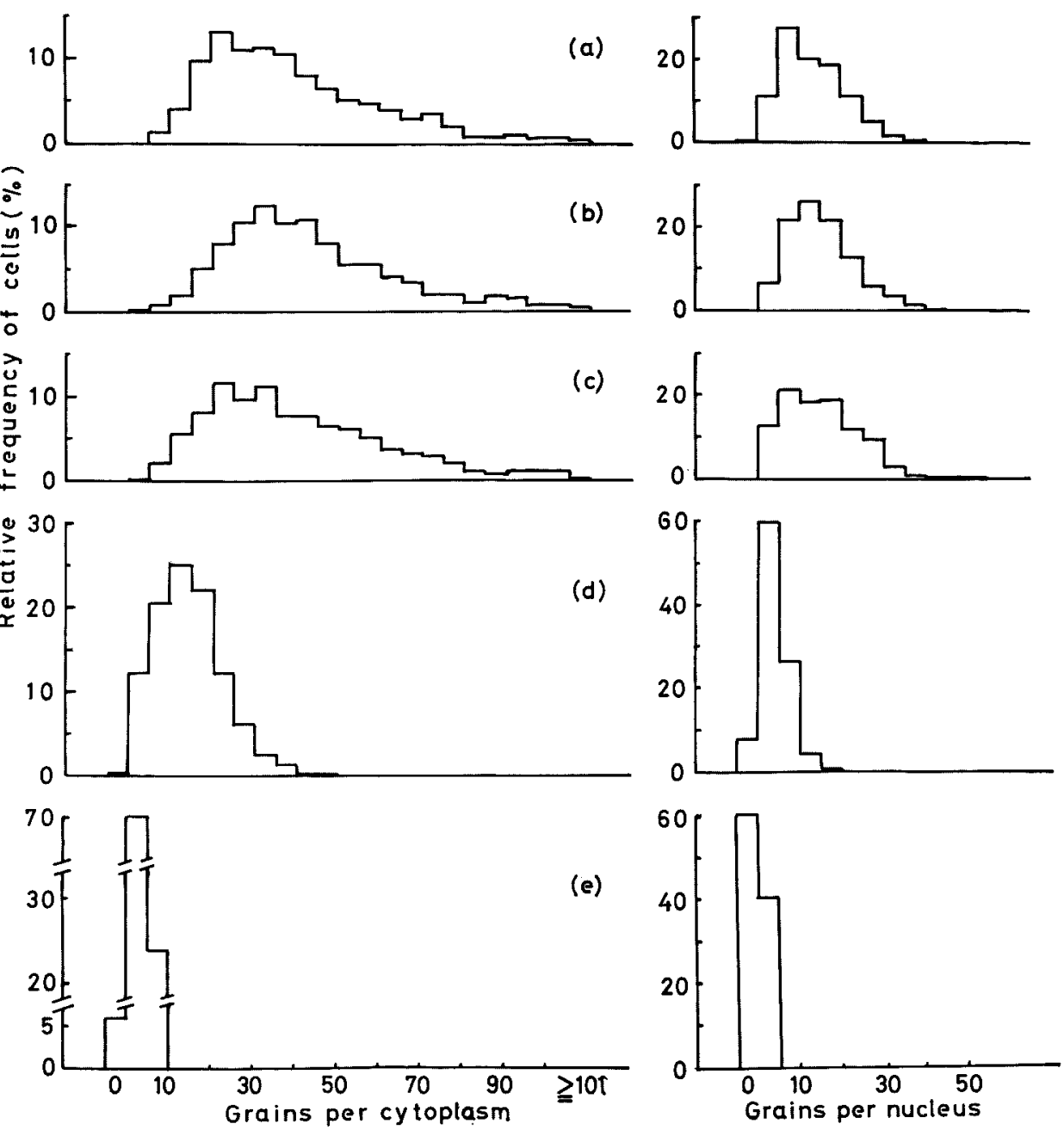

Fig. 7. Frequency distribution of the total nuclear or cytoplasmic labeled cells. a, none, b, chase for 1 hour, c, CAP (300 $\mu \mathrm{g} / \mathrm{ml}), \mathrm{d}, \mathrm{CH}(10 \mu \mathrm{g} / \mathrm{ml})$, and e, background.

$(10 \mu \mathrm{g} / \mathrm{ml})$. $\mathrm{CH}$ inhibited undoubtly the protein synthesis revealed by incorporation of ${ }^{3} \mathrm{H}$-lysine, whereas it was hardly probable that $300 \mu \mathrm{g} / \mathrm{ml}$ of CAP depressed it (Fig. 7). Moreover, ratio of the incorporation between nucleus and cytoplasm was 1 to 3 in every treatment. It seems that $\mathrm{CH}$ depressed uniformly the protein syntheses in nucleus and cytoplasm. 


\section{Discussion and conclusion}

It has been generally recognized that the antibiotics, $\mathrm{CAP}, \mathrm{CH}$ or $\mathrm{PU}$ is the inhibitor of protein synthesis in bacteria, mammalian cell and partly plant cell. The present experiment showed that when barley root tip cells were treated with CAP or $\mathrm{CH}$ at the early $\mathrm{S}$, the late $\mathrm{S}$ and the early $\mathrm{G}_{2}$ stages, chromosome fragments were induced (Fig. 2, Table 1). On the contrary, PU induced very few chromosomal aberrations (Figs. 2 and 3).

Meanwhile, it was found that chromosome number in a cell reduced when treated with $\mathrm{CAP}$ or $\mathrm{CH}$ during the $\mathrm{S}$ period (Table 2). The reduction of chromosomes seemed to be produced by chromosomal non-disjunction because DNA synthesis proceeded normally even in the presence of CAP (Fig. 6). Yoshikawa (1965) has reported that CAP allowed bacteria cells to complete the DNA synthesis which had started before CAP addition. It may be concluded from our results that non-disjunction derives from the lesions produced at $\mathrm{S}$ period. The similar results were obtained with the treatment of colchicine in Allium root (Levan 1938, Östergren 1944), of p-fluorophenylalanine in yeast (Coy and Tuveson 1964, Emeis 1966, Gutz 1966, Stömnaes 1968), or of organic mercury compounds in Allium root (Ramel 1969). Particularly, an interesting fact is that the amino acid analogue such as p-fluorophenylalanine could produce the reduction of chromosomes and often induce crossing-over.

Gillois (1969) proposed the following model on the mechanism of chromosome separation. In either case of mitosis and meiosis, homologous chromosomes pair first associating with protein band. In mitosis, such protein band is destroyed by a particular enzyme at prophase. In meiosis, however, this enzyme is not activated. If an amino acid analogue participates in the synthesis of polypeptide chain so that the enzyme is inactivated, therefore, pseudo-meiosis would be expected in somatic cell. According to this hypothesis, it is likely that treatment of CAP or CH resulted to inactivate such enzyme and consequently to produce pseudo-meiosis. Furthermore, it is acceptable to conclude that the time in which the enzyme operating on chromosome separation becomes inactive is early S. Majority of chromosome fragments induced by CAP or $\mathrm{CH}$ was chromosome type and ${ }^{3} \mathrm{H}$-thymidine did not incorporate into the chromosome fragments. This also supports strongly the above hypothesis. Thus, the following process;

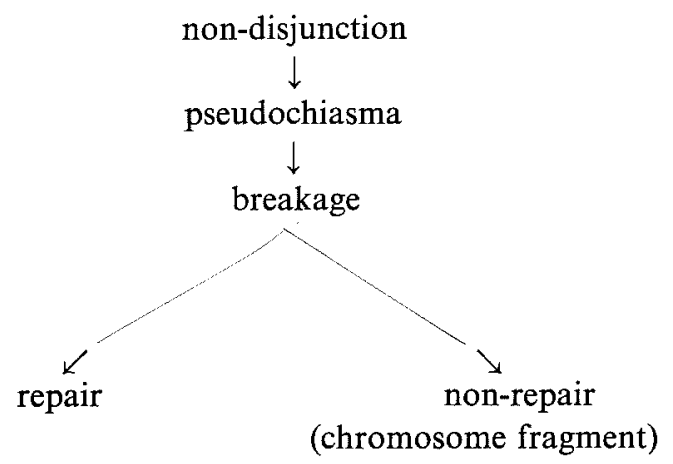


is suggested. This diagram indicates that when early or late $\mathbf{S}$ cells are treated with CAP or $\mathrm{CH}$, some pairs of homologous chromosomes are not able to separate and then pseudochiasma follows. Consequently, breaks take place in homologous mother chromosomes. Because there was no relation between chromosome fragments and reduced chromosomes (Fig. 5), it has to be taken into account that chromosome breaks repair sometimes. If this working hypothesis is correct, inter- or intra-chromosomal recombination is expected to occur during the process.

Contrary to our expectation, CAP did not affect protein synthesis even with the concentration of $300 \mu \mathrm{g} / \mathrm{ml}$ (Fig. 7). Wolff (1965) reported that at this concentration CAP decreased it about $46 \%$ in bean root meristematic cells. Recent results have pointed out that the major site which CAP attacks primarily in beet disk is oxidative phosphorylation and not protein synthesis (MacDonald and Ellis 1966 and 1967). Therefore, another possibility in CAP treatment is that chromosomal non-disjunction is caused by inactivation of the enzyme via an inhibition of oxidative phosphorylation in cell.

\section{Summary}

Barley root meristematic cells were treated with three antibiotics known as the inhibitors of protein synthesis, i.e., chloramphenicol (CAP), cycloheximide (CH) and puromycin (PU), at each stage of the interphase in first cell cycle. The results indicated that both $\mathrm{CAP}$ and $\mathrm{CH}$ induced the chromosome fragments of dot type after the treatment in early $S$, late $S$ or early $G_{2}$ cells, but PU produced no chromosomal aberrations. These chromosome fragments seemed to be produced by a 1-hit event.

On the other hand, $\mathrm{S}$ cells treated with $\mathrm{CAP}$ or $\mathrm{CH}$ markedly reduced the number of chromosomes in a cell. The chromosome reduction is likely due to the nondisjunction of chromosomes.

Moreover, $\mathrm{CH}$ inhibited the protein synthesis as revealed by the incorporation of ${ }^{3} \mathrm{H}$-lysine, but CAP did not depress at the concentrations used. It was discussed that chromosome fragments are attributable to the chromosome nondisjunction.

\section{References}

Beatty, A. V. and Beatty, J. W. 1963. Radiation recovery enhanced through inhibitors of protein synthesis and amino acids. Proc. Natl. Acad. Sci. U.S. 49: 434-439.

Coy, D. D. and Tuveson, R. W. 1964. The effects of supplementation and plating densities on apparently aberrant meiotic and mitotic segregation in Aspergillus rugulosus. Genetics 50: $847-853$.

De, D. N. 1968. Protein moiety of chromosomes. Proc. XII Intern. Cong. Genetics II: 72-73.

De Lozzio, C. B. and Valencia, J. I. 1965. Modification of breakage and reunion in relation to lethal damage. Natl. Cancer Inst. Monograph 18: 181-212.

Ellis, R. J. and MacDonald, I. R. 1967. Activation of protein synthesis by microsomes from aging beet disks. Plant Physiol. 42: 1297-1302.

Emeis, C. C. 1966. Haploidisierung von diploiden Hefen durch p-Fluorophenylalanine. Z. Naturforschg. 21: 816-817.

Gillois, M. 1969. Modele de l'induction de pseudo-meioses produisant des cellules haploides. 
Compt. Rend. Acad. Sci. Paris, Serie D 268: 602-604.

Gutz, H. 1966. Induction of mitotic segregation with p-fluorophenylalanine in Schizosaccharomyces pombe. J. Bacteriol. 92: 1567-1568.

Levan, A. 1938. The effect of colchicine on root mitoses in Allium. Hereditas 24: 471-486.

MacDonald, I. R., Bacon, S. D., Vaughan, D. and Ellis, R. J. 1966. The relation between ion absorption and protein synthesis in beet disks. J. Exptl. Botany 17: 822-837.

Östergren, G. 1944. Colchicine mitosis, chromosome contraction, narcosis and protein chain folding. Hereditas 30: 429-467.

Quastler, H. 1960. Cell population kinetics. Ann. N. Y. Acad. Sci. 90: 580-591.

Ramel, C. 1969 . Genetic effects of organic mercury compounds. I. Cytological investigations on Allium roots. Hereditas 61: 208-230.

Stömnaes, Ö. 1968. Genetic changes in Saccharomyces cerevisiae grown on media containing DL-para-fluorophenylalanine. Hereditas 59: 197-220.

Wolff, S. 1965. On the chemistry of chromosome continuity. Natl. Cancer Inst. Monograph 18: $155-180$.

- 1969. The splitting of human chromosome into chromatids in the absence of either DNA or protein synthesis.-Mutation Res. 8: 207-214.

Yamamoto, K. and Yamaguchi, H. 1966. Radiation-induced chromosomal aberration in relation to DNA synthesis. J. Radiation Res. 7: 115-122.

Yoshikawa, H. 1965. DNA synthesis during germination of Bacillus subtilis spores. Proc. Natl. Acad. Sci. U.S. 53: 1476-1483. 